\title{
Proximate composition and micronutrient profile of different size groups of hilsa Tenualosa ilisha (Hamilton, 1822) from river Ganga
}

\author{
S. GANGULY, A. MAHANTY, T. MITRA AND B. P. MOHANTY \\ ICAR-Central Inland Fisheries Research Institute, Barrackpore, Kolkata - 700 120, West Bengal, India \\ e-mail: bimalmohanty12@rediffmail.com
}

\begin{abstract}
The Indian shad hilsa, Tenualosa ilisha (Hamilton, 1822) is an important food fish in South-east Asian countries. The fish is rich in oil and known for its high omega-3 polyunsaturated fatty acid (PUFA) content; however information available on the micronutrient profile of this commercially important food fish is limited. The present study investigated the detailed micronutrient profile (mineral and fat soluble vitamins) of different size groups of hilsa. Proximate composition analysis revealed that besides being rich in crude fat (7.91-14.61\%), the protein content of this fish is also very high (19.44-21.86\%). The macro-minerals potassium, calcium and micro-minerals iron, zinc and the fat soluble vitamins $\mathrm{A}$ and $\mathrm{E}$ are the dominant micronutrients in different size groups of hilsa. Comparative nutritional evaluation of different size groups of hilsa showed that medium size fish is nutritionally superior to both small and large size groups.
\end{abstract}

Keywords: Fat soluble vitamins, Hilsa, Micronutrients, Proximate composition, Tenualosa ilisha

\section{Introduction}

Micronutrients are needed only in minuscule amounts but enable the body to produce enzymes, hormones and other substances essential for proper growth and development and the consequences of their absence are significant. Therefore, the current practice of evaluating nutritive value of diets emphasises the need for energy and protein adequacy in addition to micronutrient density of the diet (Mohanty et al., 2016a). Micronutrient deficiency is a form of malnutrition and is a recognised health problem in many of the developing countries. People from developed countries also suffer from various forms of micronutrient deficiencies and diets which lack adequate amount of minerals and vitamins lead to diseases (WHO, 2006). Approximately one third of the developing world's children under the age of five are vitamin A-deficient and therefore ill-equipped for survival as vitamin A deficiency is often associated with protein calorie malnutrition (PCM). Iron deficiency anaemia during pregnancy is associated with $1,15,000$ deaths each year, accounting for one fifth of total maternal deaths (Mohanty et al., 2016a).

The anadromous clupeid Tenualosa ilisha (hilsa) is an important food fish and is widely distributed in the coastal waters from Persian Gulf, Pakistan, India, Bangladesh, Myanmar to North Sumatra. It is most abundant in the Ganges-Brahmaputra drainage system of India and Bangladesh, forming one of the most important commercial fisheries of single species in the countries around the Bay of Bengal (Alam et al., 2012).
Hilsa is long known to be rich in oils, especially the polyunsaturated fatty acids (PUFAs), eicosapentaenoic acid (EPA) and docosahexaenoic acid (DHA) (Mohanty et al., 2012b; 2016b). It ranks high among the edible fishes due to its superb taste, mouth-watering flavour and delicate culinary properties (Ganguly et al., 2017). The nutritional composition varies with age, season and size of fish. Although hilsa is long- known to be an oil rich species (Mohanty et al., 2012b; Nath and Banerjee, 2012) and many aspects of its nutritional composition have been reported (Kamal et al., 1996; Pal et al., 2011; Rao et al., 2012), comprehensive information on micronutrient profile of different size groups of hilsa has not been reported except for a recent report by Hossain et al. (2014) on mineral composition of hilsa from Bay of Bengal and Arabian Sea. In the present study, the comparative proximate composition and micronutrient profile of different size groups of hilsa from river Ganga, India is reported.

\section{Materials and methods}

\section{Sample collection}

Hilsa (males) were collected from different fish landing centres of river Ganga in Kolkata, India and transported in ice to the laboratory. After thorough cleaning in running tap water, length and weight of each fish was recorded. They were cut into fillets and stored at $-40^{\circ} \mathrm{C}$. The fishes were divided into three size groups based on their weight and length : small (200-400 g, 20-25 cm), medium (800-1000 g, $33-37 \mathrm{~cm})$ and large $(1200-1500 \mathrm{~g}, 39-43 \mathrm{~cm})$ size. Fifteen fishes from each group were used for analysis. 


\section{Proximate composition}

The proximate composition viz., moisture, crude fat, crude protein and ash contents of fillets (muscle tissue after removing the inedible offal) were determined according to AOAC (2006). The minced samples were kept in an oven at $105 \pm 2^{\circ} \mathrm{C}$ overnight, until constant weight was obtained. The crude protein and crude fat contents were estimated by Kjeldahl and Soxhlet methods, respectively (AOAC, 2006). Ash content was determined by incinerating known weight of dry sample at high temperature $\left(600^{\circ} \mathrm{C}\right.$ for $\left.6 \mathrm{~h}\right)$ in muffle furnace (AOAC, 2006).

Minerals

Mineral composition was analysed by inductively coupled plasma-mass spectrometry (ICP-MS) (Thermo, $\mathrm{X}$ series 2). Briefly, dried fish powders ( $0.5 \mathrm{~g})$ were weighted in glass digestion bombs and $3 \mathrm{ml}$ suprapure $\mathrm{HNO}_{3}$ was added to the samples. The bombs were firmly closed and put in the microwave oven (MDS-Anton Paar, Multiwave 3000) for digestion under controlled pressure. The basic program for the microwave digestion is given in Table 1. After digestion, the glass bombs were cooled and the mineralised samples were diluted to $50 \mathrm{ml}$ with milliQ water. The micro minerals iron, copper, zinc and manganese were directly analysed in ICP-MS whereas the macro minerals were analysed after appropriately diluting the samples. A multi element stock standard (1.09494.0100 and 1.09492.0100, E. Merck) was used, after appropriate dilution for instrument calibration and sample spiking. The ICP-MS operation and measurement conditions are given in Table 2.

Table 1. Microwave digestion programme

\begin{tabular}{llll}
\hline Step & Power $(\mathrm{W})$ & Ramp time $(\mathrm{min})$ & Hold time $(\mathrm{min})$ \\
\hline 1 & 300 & 05.00 & 05.00 \\
2 & 400 & 10.00 & 10.00 \\
3 & 600 & 10.00 & 05.00 \\
\hline
\end{tabular}

Table 2. The ICP-MS operating conditions and measurement conditions

\begin{tabular}{ll}
\hline Operating conditions & \\
\hline Spray chamber & Cyclonic Quartz \\
\hline RF Power (W) & 1398 \\
Plasma gas flow $\left(\mathrm{L} \mathrm{min}^{-1}\right)$ & 13.0 \\
Nebuliser gas flow rate $\left(\mathrm{L} \mathrm{min}^{-1}\right)$ & 0.98 \\
Auxiliary gas flow rate $\left(\mathrm{L} \mathrm{min}^{-1}\right)$ & 0.5 \\
No. of replicates & 3 \\
Isotopes & ${ }^{23} \mathrm{Na},{ }^{39} \mathrm{~K},{ }^{43} \mathrm{Ca},{ }^{24} \mathrm{Mg}$, \\
Delay time (sec) & 5 \\
Sample flush time $(\mathrm{sec})$ & 30 \\
Flush pump rate $(\mathrm{rpm})$ & 100 \\
Analysis pump rate $(\mathrm{rpm})$ & 40 \\
\hline
\end{tabular}

Fat soluble vitamins

Oil extraction from fish meat was carried out following standard protocol (Folch et al., 1957) and extracted oil was used for analysis of fat soluble vitamins A, D, E and $\mathrm{K}$ following Mohanty et al. (2012a). Briefly, about $0.15 \mathrm{~g}$ fish oil was refluxed with $25 \mathrm{ml}$ methanol and $150 \%$ potassium hydroxide $(\mathrm{KOH})$ in water bath for $30 \mathrm{~min}$. Fat soluble vitamins were extracted with $50 \mathrm{ml}$ petroleum ether (Metcalfe et al., 1966). The petroleum ether layer was collected, concentrated and partitioned in $5 \mathrm{ml}$ acetonitrile $(\mathrm{ACN})$. Fat soluble vitamins were analysed by HPLC (Shimadzu LC 10AS) equipped with $\mathrm{C}_{18} \mathrm{RP}$ column and UV detector (Chatzimichalakis et al., 2004). Twenty microliter sample was injected to the column. The mobile phase of HPLC consisted of ACN (solvent A) and methanol (solvent B). A simple linear gradient system was used, starting from (solvent A/solvent B) 50/50 to $70 / 30$ in $20 \mathrm{~min}$. The mobile

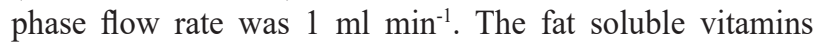
were identified and quantified by comparing retention times and peak area with those of vitamin standards for A, D, E, $\mathrm{K}$ respectively (R7632, C9756, T3251 and M5625, SigmaAldrich).

\section{Statistical analysis}

The results were subjected to analysis of variance (ANOVA) using SPSS 16.0 software and the occurrence of significance was established at $\mathrm{p}<0.05$.

\section{Results and discussion}

\section{Proximate composition}

The proximate composition of muscle tissues of different size groups of hilsa are presented in Table 3. The crude protein content of different size groups of hilsa ranged between 19.44-21.86\% which is higher than earlier reports of 18.16\% (Hossain et al., 2014); 16.80\% (Kamal et al., 1996) and similar with that reported by Nath and Banerjee (2012). The protein content of hilsa is higher than that of many other fishes like catfish Mystus vittatus (15.622\%) and Clarias batrachus (14.78\%) (Kamal et al., 2007), Sperata seenghala (20.06\%) (Mohanty et al., 2012a), salmon (19.84\%) (Atanasoff et al., 2013), anchovy (15.71\%) (Sankar et al., 2013) and Indian major carps (IMCs), Catla catla (16.20\%), Labeo rohita (15.9\%) and Cirrhinus mrigala (15.5\%) (Mohanty et al., 2014). The medium sized hilsa which has the highest content of EPA and DHA (Mohanty et al., 2012b) among the different size groups are found to contain the highest concentration of protein also $(21.86 \%)$. The crude fat content of small, medium and large size fishes was found to be 7.91, 10.47 and $14.61 \%$ respectively, showing a direct positive relation to the size of the fish. Quantitatively, oil content of hilsa is significantly higher than many of its riverine and 
Table 3. Proximate composition of differen size groups of T. ilisha from the river Ganga

\begin{tabular}{lllll}
\hline Proximate composition (\%) & Small & Medium & Large & Average \\
\hline Moisture & $69.25 \pm 2.72^{\mathrm{a}}$ & $66.46 \pm 3.75^{\mathrm{b}}$ & $61.96 \pm 3.28^{\mathrm{c}}$ & $65.89 \pm 3.01$ \\
Crude protein & $19.44 \pm 1.39^{\mathrm{a}}$ & $21.86 \pm 1.74^{\mathrm{b}}$ & $19.83 \pm 2.24^{\mathrm{c}}$ & $20.37 \pm 1.89$ \\
Crude fat & $7.91 \pm 4.13^{\mathrm{a}}$ & $10.47 \pm 3.40^{\mathrm{b}}$ & $14.61 \pm 3.17^{\mathrm{c}}$ & $10.99 \pm 3.67$ \\
Ash & $1.22 \pm 0.59^{\mathrm{a}}$ & $1.06 \pm 0.55^{\mathrm{b}}$ & $1.07 \pm 0.55^{\mathrm{c}}$ & $1.12 \pm 0.43$ \\
\hline
\end{tabular}

Values are presented as mean \pm standard deviation

Values bearing different superscripts within a row differ significantly $(\mathrm{p}<0.05)$

estuarine counterparts. Hilsa is known for its high PUFA (EPA+DHA) content (Mohanty et al., 2012b) and is also rich in proteins.

\section{Macro-minerals}

The macro-minerals studied were sodium, potassium, calcium and magnesium (Table 4). Sodium is a very important macro mineral which is needed by the body to regulate blood volume and blood pressure. Sodium content of hilsa was found to be $0.53,0.63,0.65 \mathrm{mg} \mathrm{g}^{-1}$ of wet sample in small, medium and large fishes, respectively. The mean sodium content of hilsa $\left(0.61 \mathrm{mg} \mathrm{g}^{-1}\right)$ was comparable with the sodium content of Baltic herring (Tahvonen et al., 2000), C. catla $\left(0.58 \mathrm{mg} \mathrm{g}^{-1}\right)$ and C. mrigala $\left(0.69 \mathrm{mg} \mathrm{g}^{-1}\right)$ but less than that of $L$. rohita $\left(1.12 \mathrm{mg} \mathrm{g}^{-1}\right)$ (Gopakumar, 1997).

Potassium is required for normal functioning of body. It assists in the acid-base balance, protein synthesis, carbohydrate metabolism and is also necessary for building of muscles and normal body growth. Potassium content was found to be 3.72, 4.93 and $4.16 \mathrm{mg} \mathrm{g}^{-1}$ in small, medium and large fishes, respectively. The medium size fishes were found to contain significantly high amount of potassium than the fishes of other two size groups. The mean potassium content of different size groups of hilsa $\left(4.27 \mathrm{mg} \mathrm{g}^{-1}\right)$ was higher than the IMCs, L. rohita $\left(1.32 \mathrm{mg} \mathrm{g}^{-1}\right)$, C. catla $\left(1.62 \mathrm{mg} \mathrm{g}^{-1}\right)$ and C. mrigala (1.70 $\mathrm{mg} \mathrm{g}^{-1}$ ) (Gopakumar, 1997), Baltic herring
(2993-4742 $\mathrm{mg} \mathrm{kg}^{-1}$ ) (Tahvonen et al., 2000), seabass (4597 $\left.\mathrm{mg} \mathrm{kg}^{-1}\right)$, sea bream (3.94 $\left.\mathrm{mg} \mathrm{g}^{-1}\right)$ (Erkan and Ozden, 2007), blue whiting (3.88 $\left.\mathrm{mg} \mathrm{g}^{-1}\right)$ and trout $\left(3.06 \mathrm{mg} \mathrm{g}^{-1}\right.$ ) (LidwinKazmierkiewicz et al., 2009).

Calcium is one of the most abundant minerals in the body that is needed for normal functioning of muscles and nervous system. It also plays an important role in blood clotting process. Deficiency of calcium may be associated with rickets in young children and osteomalacia (softening of bones) in adults and older people. The calcium content of hilsa was $1.03,1.19$ and $1.10 \mathrm{mg} \mathrm{g}^{-1}$ in small, medium and large sized fishes, respectively. The medium size fishes were found to contain higher amount of calcium than the other two size groups but the difference was not significant. The mean calcium content of different size groups of fishes (1.10 $\mathrm{mg} \mathrm{g}^{-1}$ ) was found to be much higher than that of Cyprinus carpio (384 mg kg-1) (Lidwin-Kazmierkiewicz et al., 2009), blue whiting $\left(0.17 \mathrm{mg} \mathrm{g}^{-1}\right)$ (Martinez et al., 2000) and European perch (Orban et al., 2007), L. rohita $\left(0.86 \mathrm{mg} \mathrm{g}^{-1}\right)$ (Gopakumar, 1997) but less than that of C. catla $\left(4.95 \mathrm{mg} \mathrm{g}^{-1}\right)$ and C. mrigala (3.52 $\mathrm{mg} \mathrm{g}^{-1}$ ) (Gopakumar, 1997).

The concentration of magnesium in different size groups of hilsa ranged between $0.29-0.38 \mathrm{mg} \mathrm{g}^{-1}$. Medium size fishes contained significantly high amount of magnesium than the other two size groups. The average magnesium content

Table 4. Mineral content of different size group of T. ilisha from the river Ganga

\begin{tabular}{|c|c|c|c|c|}
\hline \multirow{2}{*}{ Elements } & \multicolumn{3}{|c|}{ Tenualosa ilisha } & \multirow{2}{*}{ Average } \\
\hline & Small & Medium & Large & \\
\hline \multicolumn{5}{|c|}{ Macro minerals $\left(\mathrm{mg} \mathrm{kg}^{-1}\right)$} \\
\hline Sodium & $0.53 \pm 180.82^{\mathrm{a}}$ & $0.63 \pm 77.31^{\mathrm{a}}$ & $0.65 \pm 148.84^{\mathrm{a}}$ & $0.60 \pm 100.23$ \\
\hline Potassium & $3.72 \pm 379.39^{\mathrm{a}}$ & $4.93 \pm 176.14^{b}$ & $4.16 \pm 746.04^{\mathrm{a}}$ & $4.27 \pm 960.19$ \\
\hline Calcium & $1.04 \pm 168.45^{\mathrm{a}}$ & $1.19 \pm 456.93^{\mathrm{a}}$ & $1.10 \pm 370.14^{\mathrm{a}}$ & $1.10 \pm 250.36$ \\
\hline Magnesium & $0.29 \pm 39.48^{\mathrm{a}}$ & $0.38 \pm 133.64^{\mathrm{b}}$ & $0.31 \pm 51.66^{\mathrm{a}}$ & $0.33 \pm 98.50$ \\
\hline \multicolumn{5}{|c|}{ Micro minerals $\left(\mu g g^{-1}\right)$} \\
\hline Iron & $26.63 \pm 4.77^{\mathrm{a}}$ & $30.5 \pm 7.23^{\mathrm{a}}$ & $26.56 \pm 6.39^{a}$ & $27.89 \pm 5.69$ \\
\hline Copper & $2.46 \pm 0.41^{\mathrm{a}}$ & $3.13 \pm 0.66^{\mathrm{a}}$ & $3.03 \pm 0.46^{\mathrm{a}}$ & $2.87 \pm 0.44$ \\
\hline Zinc & $7.0 \pm 0.36^{\mathrm{a}}$ & $9.6 \pm 0.95^{b}$ & $6.9 \pm 1.61^{\mathrm{a}}$ & $7.83 \pm 0.99$ \\
\hline Manganese & $2.6 \pm 0.95^{\mathrm{a}}$ & $2.76 \pm 0.30^{\mathrm{a}}$ & $2.86 \pm 1.02^{\mathrm{a}}$ & $2.74 \pm 0.45$ \\
\hline
\end{tabular}

Values are presented as mean \pm standard deviation

Values bearing different superscripts within a row differ significantly $(\mathrm{p}<0.05)$ 
$\left(0.33 \mathrm{mg} \mathrm{g}^{-1}\right)$ was notably higher than that of Baltic herring and seabass (Tahvonen et al., 2000).

The micro-minerals studied were iron, copper, zinc and manganese. Iron is a major component of hemoglobin that carries oxygen to all parts of the body. Iron also has a critical role within cells assisting in oxygen utilisation, enzymatic systems, especially for neural development and overall cell function all over the body. Thus, iron deficiency affects body functions, not only through anaemia, which appears late in the process of tissue iron deficits. The medium size hilsa were found to be richer in iron content than the other two size groups; however, the difference among the groups was insignificant. The mean iron content of different size groups of hilsa was $27.89 \mu \mathrm{g} \mathrm{g}^{-1}$, higher than that of seabass (Erkan and Ozden, 2007).

Copper is an essential element, but toxic at high concentrations. The copper content was 2.46, 3.13 and $3.03 \mu \mathrm{g} \mathrm{g}^{-1}$ in small, medium and large sized fishes, respectively. Although the medium size hilsa contained slightly higher amount of copper than the other two groups, there was no significant difference. Zinc is known to be involved in most metabolic pathways in plants, animals and humans. Zinc deficiency can lead to loss of appetite, growth retardation, skin problems and also immunological abnormalities. The level of zinc in different size groups of hilsa were $6.09,9.6$ and $6.9 \mu \mathrm{g} \mathrm{g}^{-1}$ in small, medium and large size fishes, respectively. The difference in zinc content in small and large fishes was not significant but the medium size fishes were found to contain significantly higher amount of zinc than the other two size groups $(p<0.05)$. However, the zinc content of medium size hilsa $\left(9.6 \mu \mathrm{g} \mathrm{g}^{-1}\right)$ is lower than that of $S$. seenghala $\left(29.4 \mu \mathrm{g} \mathrm{g}^{-1}\right)$, Cirrhinus cirrohosus $\left(15.0 \mu \mathrm{g} \mathrm{g}^{-1}\right)$ and Channa punctata $\left(15.0 \mu \mathrm{g} \mathrm{g}^{-1}\right)$ (Roos et al., 2003) and small indigenous fishes (SIFs) Amblypharyngodon mola (32.0 $\mu \mathrm{g} \mathrm{g}^{-1}$ ) (Kongsbak et al., 2008) and Puntius sophore $\left(31.0 \mu \mathrm{g} \mathrm{g}^{-1}\right)$ (Mahanty et al., 2014). The average zinc content of the fish was $7.83 \mu \mathrm{g} \mathrm{g}^{-1}$ which is comparable to that of mackerel (3.01-10.99 $\mu \mathrm{g} \mathrm{g}^{-1}$ ) (Ikem and Egiebor, 2005).

\section{Fat soluble vitamins}

The fat soluble vitamins studied were vitamin A, D, $\mathrm{E}$ and $\mathrm{K}$ (Table 5). Vitamin $\mathrm{A}$ is required for normal vision and for growth of bones. Vitamin A derivative retinoic acid regulates gene expression in the development of epithelial tissue. Vitamin A plays major role in combating diseases like malaria (Zeba et al., 2008). The vitamin A content was found to be $8849.1,7129.3$ and $7509.2 \mu \mathrm{g} \mathrm{kg}^{-1}$ wet sample in small, medium and large size fishes, respectively. The variation in vitamin A content was found to be statistically significant with small size fish having highest amount $(\mathrm{p}<0.05)$. The vitamin A content of hilsa was found to be higher than twenty different fish species including mackerel, salmon, dogfish (Dias et al., 2003), rainbow trout $\left(22.3 \mu \mathrm{g} 100 \mathrm{~g}^{-1}\right)$ (Stancheva et al., 2010), Indian catfish $S$. seenghala $\left(1687.35 \mu \mathrm{g} \mathrm{kg}^{-1}\right)$ (Mohanty et al., 2012a), common carp $\left(23.52 \mu \mathrm{g} 100 \mathrm{~g}^{-1}\right)$ and European catfish $\left(6.30 \mu \mathrm{g} 100 \mathrm{~g}^{-1}\right)($ Ozyurt et al., 2009).

Vitamin D possesses curative properties for chronic diseases like osteoporosis, cancer, cardiovascular diseases and diabetes (Holick, 2007). Vitamin D present in fish liver and oils is crucial for bone growth since it is essential for absorption and metabolism. Recent studies have found that lower serum vitamin $\mathrm{D}$ concentration is associated with depression and mood disorders (Ganji et al., 2010). Wide range of variation was observed in vitamin D content of different size groups of hilsa. The vitamin D content was found to be 2458.2, 1336.0 and $3369.3 \mu \mathrm{g} \mathrm{kg}^{-1}$ of wet sample in small, medium and large size fishes, respectively which is higher than values reported in L. rohita $\left(52.1 \mu \mathrm{g} \mathrm{kg}^{-1}\right)$, C. catla $\left(14.8 \mu \mathrm{g} \mathrm{kg}^{-1}\right)$, C. mrigala (50.8 $\mu \mathrm{g} \mathrm{kg}^{-1}$ ) (Anon., 2014), broad whitefish, Coregonus nasus ( $\left.85 \mathrm{ng} \mathrm{g}^{-1}\right)$, broad whitefish fillet (55 $\left.\mathrm{ng} \mathrm{g}^{-1}\right)$ and pink salmon fillet (89.75 $\mathrm{ng} \mathrm{g}^{-1}$ ), while comparable with pink salmon liver $\left(1,304.25 \mathrm{ng} \mathrm{g}^{-1}\right)$, arctic char $\left(1,589.50 \mathrm{ng} \mathrm{g}^{-1}\right)$ and broad whitefish, C. nasus (2,472.67 $\mathrm{ng} \mathrm{g}^{-1}$ ) (Kenny et al., 2004).

Vitamin E is considered as a potent lipid soluble antioxidant. Besides, it plays many important physiological roles in oxidation of low density lipids and enzymatic reactions (Boscoboinik et al., 1991). Vitamin $\mathrm{E}$ is the most abundant fat soluble vitamin present in hilsa and its levels recorded during the present investigations were, 8592.9, 8415.4 and $9546.2 \mu \mathrm{g} \mathrm{kg}^{-1}$ in small, medium and large size hilsa, respectively. The vitamin content in each group of

Table 5. Fat soluble vitamin content of T. ilisha $\left(\mu \mathrm{g} \mathrm{kg}^{-1}\right)$ from the river Ganga

\begin{tabular}{lllll}
\hline Vitamins $\left(\mu \mathrm{g} \mathrm{kg}^{-1}\right)$ & \multicolumn{3}{c}{ T. ilisha } & \multirow{2}{*}{ Average } \\
\cline { 2 - 4 } & Small & Medium & Large & $7829.2 \pm 60.12$ \\
\hline $\mathrm{A}$ & $8849.1 \pm 76.58^{\mathrm{a}}$ & $7129.3 \pm 59.86^{\mathrm{b}}$ & $7509.2 \pm 59.69^{\mathrm{c}}$ & $2387.3 \pm 5.4$ \\
$\mathrm{D}$ & $2458.2 \pm 5.7^{\mathrm{a}}$ & $1336.0 \pm 6.0^{\mathrm{b}}$ & $3369.3 \pm 5.7^{\mathrm{c}}$ & $8851.5 \pm 48.56$ \\
$\mathrm{E}$ & $8592.9 \pm 50.4^{\mathrm{a}}$ & $8415.4 \pm 47.62^{\mathrm{b}}$ & $9546.2 \pm 63.1^{\mathrm{c}}$ & $1741.45 \pm 25.2$ \\
$\mathrm{~K}$ & $2018.0 \pm 5.7^{\mathrm{a}}$ & $1163.85 \pm 62.5^{\mathrm{b}}$ & $2042.5 \pm 37.8^{\mathrm{c}}$ & \\
\hline
\end{tabular}

Values are presented as mean \pm standard deviation

Values bearing different superscripts within a row differ significantly $(\mathrm{p}<0.05)$ 
hilsa was higher than reported for C. catla $\left(3636 \mu \mathrm{g} \mathrm{kg}^{-1}\right)$ (Anon., 2014) and C. carpio (0.46 mg $100 \mathrm{~g}^{-1}$ ) (Ozyurt et al., 2009) but comparable with L. rohita $\left(7999 \mu \mathrm{g} \mathrm{kg}^{-1}\right)$, C. mrigala (7090.9 $\mu \mathrm{g} \mathrm{kg}^{-1}$ ) (Anon., 2014), S. seenghala (8654.25 $\mu \mathrm{g} \mathrm{kg}^{-1}$ ) (Mohanty et al., 2012a), pike perch $\left(0.94 \mathrm{mg} 100 \mathrm{~g}^{-1}\right)$ and European catfish $\left(0.80 \mathrm{mg} 100 \mathrm{~g}^{-1}\right)$ (Ozyurt et al., 2009).

Vitamin $\mathrm{K}$ acts as an essential cofactor for carboxylation of certain glutamate residues to $\gamma$-carboxy-glutamate residue in a selected number of proteins. The majority of known $\gamma$-carboxy-glutamate containing or vitamin $\mathrm{K}$ dependant proteins are involved in blood coagulation. Vitamin $\mathrm{K}$ content in hilsa was found to be 2018.0, 1163.85 and $2042.5 \mu \mathrm{g} \mathrm{kg}^{-1}$ in small, medium and large size groups, respectively. The average vitamin $\mathrm{K}$ content in medium size fish was lower than that in the small and large size fish, however, the vitamin $\mathrm{K}$ content in all the three size groups was higher than IMCs C. catla $\left(72 \mu \mathrm{g} \mathrm{kg}^{-1}\right)$, L. rohita (14.5 $\left.\mu \mathrm{g} \mathrm{kg}^{-1}\right)$ and C. mrigala (72 $\mu \mathrm{g} \mathrm{kg}^{-1}$ ) (Anon, 2014).

Comparative nutritional evaluation of different size groups of hilsa showed that medium size hilsa is micronutrient rich and superior to both small and large size hilsa in terms of minerals potassium, calcium, iron and vitamin $\mathrm{A}$ and $\mathrm{E}$ content. Our earlier studies have shown that medium size hilsa is rich in PUFA, have higher EPA+DHA content, higher $\omega-3 / \omega-6$ ratio and have low artherogenic and thrombogenic index (Mohanty et al., 2012b). Hence it can be concluded that the medium size hilsa (800-1000 g) is nutritionally superior among the different size groups.

\section{Acknowledgements}

This work was supported by the ICAR, New Delhi under the Outreach Activity on "Nutrient profiling and evaluation of fish dietary component (OA\#3)". The authors (SG, AM, TM) are thankful to the ICAR for financial assistance. The authors are thankful to Dr. S. Ayyappan, former Secretary DARE and DG, ICAR; Dr. B. Meenakumari former DDG (Fisheries Science) for the funding, guidance and encouragement and Dr. A. P. Sharma, Director, ICAR-CIFRI for the facilities and encouragement.

\section{References}

Alam, A. K. M. N., Mohanty, B. P., Hoq, M. E. and Thilsted, S. H. 2012. Nutritional values, consumption and utilisation of hilsa Tenualosa ilisha (Ham.). In: Proceedings of Regional Workshop on Hilsa: Status of Fishery and Potential for Aquaculture, 16-17 September 2012, Dhaka, Bangladesh, p. $183-215$.

Anon, 2014. Final report. Outreach Activity \# 3 Consortium: Nutrient profiling and evaluation of fish as a dietary component, Fisheries Division, Indian Council of Agricultural Research, New Delhi, India.

AOAC 2006. Official methods of analysis. $18^{\text {th }}$ edn. Association of Official Analytical Chemists, Gaithersburg, MD, USA.
Atanasoff, A., Nikolov, G., Staykov, Y., Zhelyazkov, G. and Sirakov, I. 2013. Proximate and mineral analysis of Atlantic salmon (Salmo salar) cultivated in Bulgaria. Biotechnol. Anim. Husbandry, 29(3): 571-579.

Boscoboinik, D., Szewczyk, A., Hensey, C. and Azzi, A. 1991. Inhibition of cell proliferation by a-tocopherol. Role of protein kinase C. J. Biol. Chem., 266: 6188-6194.

Chatzimichalakis, P. M., Samanidou, V. F. and Papadoyannis, J. N. 2004. Development of validated liquid chromatography method for the simultaneous determination of eight fat-soluble vitamins in biological fluids after solid-phase extraction. J. Chromatogr. B Analyt. Technol. Biomed. Life Sci., 805: 289-296.

Dias, M. G., Sanchez, M. V., Bartolo, H. and Oliveira, L. 2003. Vitamin content of fish and fish products consumed in Portugal, Electron. J. Environ. Agri. Food Chem., 2: 510-513.

Erkan, N. and Ozden, O. 2007. Proximate composition and mineral contents in aqua cultured seabass (Dicentrarchus labrax), sea bream (Sparus aurata) analysed by ICP-MS. Food Chem., 102: 721-725.

Folch, J., Lees, M. and Sloane-Stanley, G. H. 1957. A simple method for the isolation and purification of total lipids from animal tissues. J. Biol. Chem., 226: 497-509.

Ganguly, S., Mahanty, A., Mitra, T., Raman, R. K. and Mohanty, B. P. 2017. Volatile compounds in hilsa (Tenualosa ilisha, Hamilton) as detected by static headspace gas chromatography and mass spectrometry. J. Food Process. Preserv., DOI: 10.1111/ jfpp.13212.

Ganji, V., Milanoe, C., Cody, M. M., Mccarty, F. and Wang, Y. T. 2010. Serum vitamin D concentrations are related to depression in young adult US population: the third national health and nutrition examination survey. Int. Arch. Med., 3(29): 1-8.

Gopakumar, K. 1997. Biochemical composition of Indian food fish. Central Institute of Fisheries Technology (ICAR) Cochin, India.

Holick, M. F. 2007. Vitamin D deficiency. New Engl. J. Med., 357: 266-281.

Hossain, M. A., Almatar, S. M. and Al-Hazza, A. A. 2014. Proximate, fatty acid and mineral composition of hilsa, Tenualosa ilisha (Hamilton 1822) from the Bay of Bengal and Arabian Gulf. Indian J. Fish., 61(2): 58-66.

Ikem, A. and Egiebor, N. O. 2005. Assessment of trace elements in canned fishes (mackerel, tuna, salmon, sardines and herring) marketed in Georgia and Alabama, United States of America. J. Food Comp. Anal., 18: 771-787.

Kamal, M., Islam, M. N., Monsur, M. A., Hossain, M. A. and Bhuiyan, M. A. I. 1996. Biochemical and sensory evaluation of hilsa fish (Hilsa ilisha) during frozen storage. Indian J. Mar. Sci., 25: 320-323.

Kamal, D., Khan, A. N., Rahaman, M. A. and Ahamed, F. 2007. Biochemical composition of some small indigenous 
freshwater fishes from the River Mouri, Khulna, Bangladesh. Pak. J. Biol. Sci., 10(9): 1559-1561.

Kenny, D. E., O'Hara, T. M., Chen, T. C., Lu, Z., Tian, X. and Holick, M. F. 2004. Vitamin D content in Alaskan Arctic zooplankton, fishes and marine mammals. Zoo. Biol., 23: 33-43.

Kongsbak, K., Thilsted, S. H. and Wahed, M. A. 2008. Effect of consumption of the nutrient-dense, freshwater small fish Amblypharyngodon mola on biochemical indicators of vitamin A status in Bangladeshi children: a randomised, controlled study of efficacy. Br. J. Nutr., 99: 581-597.

Lidwin-Kazmierkiewicz, M., Pokorska, K., Protasowicki, M., Rajkowska, M. and Wechterowicz, Z. 2009. Content of selected essential and toxic metals in meat of freshwater fish from west Pomerania, Poland. Pol. J. Food Nutr. Sci., 59: $219-224$

Mahanty, A., Ganguly, S., Verma, A., Sahoo, S., Mitra, P., Paria, P., Sharma, A. P., Singh, B. K. and Mohanty, B. P. 2014. Nutrient profile of small indigenous fish Puntius sophore: proximate composition, amino acid, fatty acid and micronutrient profiles. Natl. Acad. Sci. Lett., 37(1): 39-44.

Martinez-Valverde., I., Periago, M. J., Santaella, M. and Ros, G. 2000. The content and nutritional significance of minerals on fish flesh in the presence and absence of bone. Food Chem., 71: 503-509.

Metcalfe, L. D., Schmitz, A. A. and Petha, J. R. 1966. Rapid preparation of fatty acid esters from lipids for gas chromatography analysis. Anal. Chem., 38: 514-517.

Mohanty, B. P., Paria, P., Das, D., Ganguly, S., Mitra, P., Verma, A., Sahoo, S., Mahanty, A., Aftabuddin, Md., Behera, B. K., Sankar, T. V. and Sharma, A. P. 2012a. Nutrient profile of giant river-catfish Sperata seenghala (Sykes). Natl. Acad. Sci. Lett., 35: 155-161.

Mohanty, B. P., Paria, P., Mahanty, A., Behera, B. K., Mathew, S., Sankar, T. V. and Sharma, A. P. 2012b. Fatty acid profile of Indian shad Tenualosa ilisha and its dietary significance. Natl. Acad. Sci. Lett., 35: 263-269.

Mohanty, B. P., Sankar, T. V., Ganguly, S., Mahanty, A., Anandan, R., Chakrabarty, K., B. N., Sarma, D., Dayal, J. S., Mathew, S., Asha, K. K., Karunakaran, D., Mitra, T., Chanda, S., Shahi, N., Das, P., Das, P., Akhtar, M. S., Vijayagopal, P. and Sridhar, N. 2016a. Micronutrient composition of 35 food fishes from India and their significance in human nutrition. Biol. Trace Elem. Res., 174: 448-458.

Mohanty, B. P., Ganguly, S., Mahanty, A., Sankar, T. V., Anandan, R., Chakrabarty, K.., Paul, B. N., Sarma, D., Dayal, J. S., Venkateswarlu, G., Mathew, S., Asha, K. K., Karunakaran, D., Mitra, T., Chanda, S., Sahi, N., Das, P., Das, P., Akhtar, M. D., Vijayagopal, P. and Sridhar, N. 2016b. DHA, EPA content and fatty acid profile of 39 food fishes from India. Biomed Res. Int., DOI:10.1155/2016/4027437.
Nath, A. K. and Banerjee, B. 2012. Comparative evaluation of body composition of hilsa, Tenualosa ilisha (Hamilton, 1822) in different size groups with special reference to fatty acid in Hooghly estuarine system, West Bengal, India. Indian J. Fish., 59(2): 141-146.

Orban, E., Nevigato, T., Masci, M., Di Lena, G., Casini, I., Caproni, R., Gambelli, R., De Angelis, L. and Rampacci, P. 2007. Nutritional quality and safety of European perch (Perca fluviatilis) from three lakes of Central Italy. Food Chem., 100: 482-490.

Ozyurt, G., Polat, A. and Loker, G. B. 2009. Vitamin and mineral content of pike perch (Sander lucioperca), common carp (Cyprinus carpio), and European catfish (Silurus glanis). Turk. J. Vet. Anim. Sci., 33: 351-356.

Pal, M., Mukhopadhyay, T. and Ghosh, S. 2011. Proximate, fatty acid and amino acid compositions of fish muscle and egg tissue of hilsa (Tenualosa ilisha). J. Aquat. Food Prod. Technol., 20(2): 160-171.

Rao, B. M., Murthy, L. N., Mathew, S., Asha, K. K., Sankar, T. V. and Prasad, M. M. 2012. Changes in the nutritional profile of Godavari hilsa shad, Tenualosa ilisha (Hamilton, 1822) during its anadromous migration from Bay of Bengal to the river Godavari. Indian J. Fish., 59(1): 125-132.

Roos, N., Islam, M. M., and Thilsted, S. H. 2003. Small fish is an important dietary source of vitamin A and calcium in rural Bangladesh. J. Nutr., 133: 4021S-4026S.

Sankar, T. V., Anandan, R., Mathew, S., Asha, K. K., Lakshmanan, P. T., Varkey, J., Aneesh, P. A. and Mohanty, B. P. 2013. Chemical composition and nutritional value of anchovy (Stolephorus commersonii) caught from Kerala coast, India. Eur. J. Exp. Biol., 3: 85-89.

Stancheva, M., Dobreva, D., Merdzhanova, A. and Galunska, B. 2010. Vitamin content and fatty acids composition of rainbow trout (Oncorhynchus mykiss). Bulg. Sci. Pap., 37: 117-124.

Tahvonen, R., Aro, T., Nurmi, J. and Kallio, H. 2000. Mineral content in Baltic herring and Baltic herring products. J. Food Compos. Anal., 13: 893-903.

WHO 2006. Guidelines on food fortification with micronutrients. In: Allen, L., de Benoist, B., Dary, O. and Hurell, R. (Eds.). World Health Organisation and Food and Agriculture Organisation of the United Nations, Geneva, p. 3-5.

Zeba, A. N., Sorgho, H., Rouamba, N., Zongo, I., Rouamba, J., Guiguemde, R. T., Hamer, D. H., Mokhtar, N. and Ouedraogo, J. B. 2008. Major reduction of malaria morbidity with combined vitamin $\mathrm{A}$ and zinc supplementation in young children in Burkina Faso: a randomised double blind trial. Nutr. J., 7: 7. 